\title{
Inactivation of the CDC25 gene product in Saccharomyces cerevisiae leads to a decrease in glycolytic activity which is independent of cAMP levels
}

\author{
L. J. W. M. Oehlen, $†$ M. E. Scholte, W. de Koning + and K. van Dam* \\ E.C. Slater Institute for Biochemical Research, Biotechnology Centre, University of Amsterdam, PO Box 20151, \\ 1000 HD Amsterdam, The Netherlands
}

(Received 31 December 1992; revised 25 February 1993; accepted 5 April 1993)

\begin{abstract}
In the budding yeast Saccharomyces cerevisiae cyclic AMP (cAMP) can influence the activity of key enzymes in carbohydrate metabolism through modulation of the activity of cAMP-dependent protein kinase. One of the components involved in cAMP production is the $C D C 25$ gene product, which can activate the RAS/adenylate cyclase pathway by promoting the exchange of guanine nucleotides bound to RAS. In two yeast strains carrying different thermosensitive alleles of the $C D C 25$ gene, cAMP levels respond differently to an increase in growth temperature from $23{ }^{\circ} \mathrm{C}$ (permissive) to $36^{\circ} \mathrm{C}$ (restrictive). In strain OL86 ( $\left.c d c 25-5\right)$ the estimated intracellular concentration of cAMP dropped after transfer to restrictive temperature whereas in strain ts321 $(c d c 25-1)$ the cAMP level rose under the same conditions. Despite the differences in cAMP levels the glycolytic flux in the two mutants responded in a very similar way to the shift from permissive to restrictive temperature; after the increase in the incubation temperature, the specific glycolytic flux in both $c d c 25-1$ and $c d c 25-5$ initially increased from about $300 \mathrm{nmol} \mathrm{min}^{-1}$ (mg protein) ${ }^{-1}$ to about $500 \mathrm{nmol} \mathrm{min}{ }^{-1}$ (mg protein) ${ }^{-1}$ (presumably mainly as a consequence of the increase in temperature), but then gradually fell to $100-200 \mathrm{nmol} \mathrm{min}^{-1}$ (mg protein) ${ }^{-1}$. A similar pattern of $\mathrm{CO}_{2}$ production to that found in the two $c d c 25$ mutants was also observed for several other thermosensitive mutants displaying a Start-II type of G1 arrest. In contrast, in a wild-type strain and in strains giving a Start-I type of G1 arrest, $\mathrm{CO}_{2}$ production did not drop after a temperature shift. The specific activities of glycolytic enzymes in the two $c d c 25$ mutants did not show much change after the temperature shift, indicating that the decrease in glycolytic flux was not caused by a decrease in the activity of any of the glycolytic enzymes. Our data show that, at least in long-term regulation, the cAMP levels per se are not likely to be a prime factor controlling glycolytic flux.
\end{abstract}

\section{Introduction}

Adenosine $3^{\prime}, 5^{\prime}$-phosphate (cyclic AMP, cAMP) is an important and ubiquitous regulatory molecule. In yeast it is involved in the regulation of several cellular processes, e.g. the induction of gene transcription

\footnotetext{
*Author for correspondence. Tel. 0205255125 ; fax 0205255124

†Present address: The Rockefeller University, Box 238, New York, NY 10021, USA.

†Present address: Katholieke Universiteit Leuven, Lab. voor Cellulaire Biochemie, Instituut voor Plantkunde, Kardinaal Mercierlaan 92, B-3001 Heverlee, Belgium.

Abbreviations: ADH, alcohol dehydrogenase; FBPase, fructose 1,6bisphosphatase; GAPDH, glyceraldehyde-3-phosphate dehydrogenase; G6PDH, glucose-6-phosphate dehydrogenase; HK, hexokinase; LDH, lactate dehydrogenase; PFK, phosphofructokinase; PGA, phosphoglycerate; PGI, glucose-6-phosphate isomerase; PGK, 3phosphoglycerate kinase; PGM, phosphoglycerate mutase; PK, pyruvate kinase.
}

(Tanaka et al., 1988) and control of growth and development (Matsumoto et al., 1985). Furthermore, cAMP has been implicated in the control of several enzymes involved in carbohydrate metabolism. The outlines of the mechanism by which cAMP is thought to influence glycolytic and gluconeogenic enzymes were reviewed by Hers et al. (1985). In short, cAMP is thought to exert its effects not directly as an allosteric effector of enzymes, but through the cAMP-induced dissociation of cAMP-dependent protein kinase into its regulatory and catalytic subunits. This results in the stimulation of protein kinase activity. Among the proteins which are known to be phosphorylated by the catalytic subunit are trehalase (Uno et al., 1983; Ortiz et al., 1983), phosphofructokinase-2 (PFK2, François et al., 1984) and fructose 1,6-bisphosphatase (FBPase, Purwin et al., 1982; Pohlig \& Holzer, 1985; Rittenhouse et al., 1987). PFK2 is activated by phosphorylation and then catalyses the formation of fructose 2,6-bisphosphate from fructose 
6-phosphate and ATP. Fructose 2,6-bisphosphate in its turn is a potent stimulator of PFK1 (Clifton \& Fraenkel, 1983; Nissler et al., 1983) and it also inhibits FBPase. FBPase itself is also phosphorylated and inactivated by cAMP-dependent protein kinase, a reaction which is greatly accelerated by fructose 2,6-bisphosphate. FBPase can also be inactivated by proteolytic breakdown in the vacuole (Chiang \& Schekman, 1991). The net result of all this would be that high cAMP levels stimulate PFK1 and inactivate FBPase. Although it has been shown in vitro that cAMP and fructose 2,6-bisphosphate can thus influence the activity of some key enzymes in carbohydrate metabolism, the importance of these mechanisms in vivo in controlling glycolytic and gluconeogenic fluxes remains to be established.

The CDC25 gene product in Saccharomyces cerevisiae is required for the initiation of cell division at a point or region in the cell cycle called Start (Hartwell, 1974). If the gene product in thermosensitive $c d c 25$ mutants is inactivated by switching mutant cells to the restrictive temperature, growth does not continue as rapidly as before the shift and the cells arrest in G1 prior to the point of arrest caused by $\alpha$-mating factor. Based on the retardation of growth, and because the cells arrest in a stage where they are not competent for mating, Reed (1980) classified $c d c 25$ as a Start-II mutant. The $C D C 25$ gene has been cloned and sequenced (Camonis et al., 1986; Broek et al., 1987). The CDC25 gene product is a $180 \mathrm{kDa}$ polypeptide which is strongly associated with the membrane-particulate fraction (Garreau et al., 1990; Vanoni et al, 1990). At least one of its functions is to activate the RAS/adenylate cyclase pathway by promoting the exchange of guanine nucleotides bound to RAS (Camonis et al., 1986; Broek et al., 1987; Jones et al., 1991). In this function the gene product is also involved in the generation of a glucose-induced cAMP signal (Munder \& Küntzel, 1989; Van Aelst et al., 1990). Recently Van Aelst et al. (1991) compared two thermosensitive $c d c 25$ alleles in their ability to influence the glucose-induced cAMP signal. Among other interesting findings, they found that a shift to restrictive temperature in the OL86 strain (carrying the ts-cdc25-5 allele) caused a drop in cAMP levels, whereas in ts 321 cells (carrying the ts- $c d c 25-I$ allele) the cAMP levels increased. This finding opened the possibility to modulate cAMP levels within the physiological range between 0.1 and $2 \mu \mathrm{M}$ by changing growth temperature.

In this paper we used this means of modulating cAMP levels to study the correlation between cAMP concentration and in vivo glycolytic flux. After a switch to restrictive temperature, the specific $\mathrm{CO}_{2}$ production in both $c d c 25-1$ - and $c d c 25-5$-carrying cells initially increased (presumably mainly, if not exclusively, as a consequence of the increase in temperature), but then gradually fell. Since cAMP levels were shown to respond quite differently in the $c d c 25-1$ and $c d c 25-5$ mutants (Van Aelst et al., 1991), this similarity in $\mathrm{CO}_{2}$ production response suggests that the cAMP level per se is not the prime factor controlling glycolytic flux. The specific activities of glycolytic enzymes in the two mutants did not show major changes upon the temperature shift, indicating that the decrease in glycolytic flux was not caused by a decrease in the activity of one of the glycolytic enzymes. The decrease in glycolytic activity at restrictive temperature was shown to be a common feature of many class-II Start cell cycle arrest mutants.

\section{Methods}

Yeust strains and growth conditions. The haploid strains A364A (MATu adel ade2 ural his 7 lys2 tyrl gall), ts321 (MATa cdc25-I adel ade 2 ural his 7 lys 2 tyrl gall) and OL86 (MAT 2 cdc25-5 ade 2 leu2 trpl) of Sac charomyces cerevisiae were used. A364A and ts 321 were obtained from the Yeast Genetic Stock Center (Berkeley, CA, USA) and OL86 was kindly provided by J. M. Thevelein (Leuven, Belgium).

The medium contained $6.7 \mathrm{~g}$ Yeast Nitrogen Base $\mathrm{I}^{-1}$ (Difco), $20 \mathrm{~g}$ glucose $\mathrm{l}^{-1}, 1 \mathrm{~g}$ yeast extract $\mathrm{l}^{-1}$ (Difco) and $50 \mathrm{mg} \mathrm{l}^{-1}$ appropriate supplements. The medium was buffered at $\mathrm{pH} 5.0$ with $100 \mathrm{~mm}-$ potassium phthalate.

Cells were grown aerobically in batch cultures at $23^{\circ} \mathrm{C}$ (permissive temperature) in a gyratory waterbath for at least 10 generations to an $\mathrm{OD}_{600}$ of 0.40 .6 . For temperature-shift experiments a portion of the culture was transferred to a gyratory waterbath kept at the restrictive temperature of $36^{\circ} \mathrm{C}$.

Cell growth was monitored by measurement of the $\mathrm{OD}_{600}$. Cell number, volume distribution and cell volume were determined with a Coulter Counter equipped with a $70 \mu \mathrm{m}$ orifice and a multichannel analyser as described previously (Van Doorn et al., 1988). The percentage of budded cells was determined by microscopic counting of at least 100 formatin-fixed cells after mild sonication.

Determination of CAMP. For cAMP determinations, samples (containing approximately $5 \mathrm{mg} \mathrm{dry} w \mathrm{w}$ ) were filtered on cellulose acetate filters ( $25 \mathrm{~mm}$ diam., $1.2 \mu \mathrm{m}$ pore-size, Schleicher \& Schuell), and immediately immersed in liquid nitrogen. The filters were stored in $1.5 \mathrm{ml}$ Eppendorf tubes at $-80^{\circ} \mathrm{C}$ until extraction for cAMP measurement.

For extraction, $500 \mu 12 \mathrm{M}$-perchloric acid and $0.5 \mathrm{~g}$ glass beads were added. The filters were shaken for $1 \mathrm{~h}$ on an Ika Vibrax VXR (Janke \& Kunkel) in an incubation chamber at $-10^{\circ} \mathrm{C}$. After a short spin in a microcentrifuge, $300 \mu \mathrm{l}$ perchloric extract supernatant was neutralized with $135 \mu l 3.5 \mathrm{M}-\mathrm{KOH}+1.5 \mathrm{M}-\mathrm{KHCO}_{3}$. The tubes were left open on ice for several minutes to allow all the $\mathrm{CO}_{2}$ to escape. Subsequently they were centrifuged for $5 \mathrm{~min}$ at 10000 r.p.m. to remove potassium perchlorate. A portion of supernatant $(300 \mu$ l) was lyophilized in a Speedvac vacuum concentrator (Sayant Instruments). The residue was dissolved in $60 \mu 15 \mathrm{~mm}$-potassium phosphate buffer, $\mathrm{pH}$ 7. cAMP concentrations in these extracts were determined according to Tovey et al. (1974). This cAMP test is based on the competition of cAMP with [ $\left.{ }^{3} \mathrm{H}\right] \mathrm{cAMP}$ for the regulatory subunit of bovine cAMP-dependent protein kinase.

Cellular concentrations of cAMP were calculated assuming that $1 \mathrm{~g}$ of cell material (dry wt) corresponds to $1.88 \mathrm{ml}$ cytoplasmic volume.

Determination of fructose 2,6-bisphosphate. Samples (containing about $5 \mathrm{mg}$ total cellular protein) were filtered on cellulose acetate filters (25 mm diam, $1.2 \mu \mathrm{m}$ pore-size, Schleicher \& Schuell) and 
quickly immersed in $3 \mathrm{ml}$ methanol kept at $-40^{\circ} \mathrm{C}$. The cells were resuspended and the filters removed. After addition of $5 \mathrm{ml}$ cold $\left(-40^{\circ} \mathrm{C}\right)$ chloroform, the cells were stored at $-80^{\circ} \mathrm{C}$ until extraction. Cells were extracted with $2 \times 2 \mathrm{ml}$ MOPS buffer $(4 \mathrm{~mm}, \mathrm{pH} 7)$ at $-35^{\circ} \mathrm{C}$ by vigorous shaking for one hour as described by De Koning \& Van Dam (1992). The extracts were concentrated by means of a Speedvac vacuum concentrator to a final volume of about $500 \mu \mathrm{l}$.

Fructose 2,6-bisphosphate concentrations were determined spectrophotometrically by means of the kinetic assay described by Van Schaftingen \& Hers (1983). This assay is based on the ability of fructose 2,6-bisphosphate to stimulate pyrophosphate-dependent phosphofructokinase. The degree of stimulation was measured with a Cobas Bio automatic analyser (Roche) and fructose 2,6-bisphosphate concentrations were calculated from a calibration curve in the range 0-200 nM. When necessary, extracts were diluted to bring the concentration into this range.

Determination of glycolytic fiux. $\mathrm{CO}_{2}$ production in the cultures was measured in Warburg manometers using the direct method (Umbreit et al., 1964) as described by Novak \& Mitchison (1986). Manometer flasks (volume $15 \mathrm{ml}$ ) were filled with $3 \mathrm{ml}$ culture and gas production was read every $15 \mathrm{~min}$. After each reading, the manometers were opened, adjusted to zero and closed again. Specific $\mathrm{CO}_{2}$ production rates were expressed in $\mu \mathrm{mol} \mathrm{min}^{-1}$ (mg total cellular protein) ${ }^{-1}$. The cellular protein content was calculated from the optical density of the cultures. We determined for cells of the wild-type strain that an $\mathrm{OD}_{600}$ of 10 corresponds to $1 \mathrm{mg}$ total cellular protein $\mathrm{ml}^{-2}$. For the calculation of cellular protein content in all other strains we assumed the same relation between $\mathrm{OD}_{600}$ and cellular protein.

The direct Warburg method ignores $\mathrm{O}_{2}$ consumption by the cells. The respiratory quotient (RQ) was determined to be as high as 14 which agrees with the values reported by Beck \& Von Meyenburg (1968). This high RQ, combined with the effect that, under complete oxidative conversion of glucose, $\mathrm{CO}_{2}$ production and $\mathrm{O}_{2}$ consumption take place in equimolar amounts, implies that direct manometry in our cultures closely reflects the glycolytic flux.

For alcohol and glycerol determinations, $100 \mu \mathrm{l}$ samples from the cultures were added to $1 \mathrm{ml} 5 \%(\mathrm{w} / \mathrm{v})$ trichloroacetic acid. After spinning down the cells, alcohol and glycerol concentrations in the supernatants were determined spectrophotometrically on a Cobas Bio automatic analyser (Roche). Alcohol was measured according to Bernt \& Gutmann (1974), using a commercially available glycine buffer with trapping agent (Sigma), and glycerol was measured by the protocol of Wieland (1974).

Strictly speaking the glycolytic pathway only comprises the reactions catalysed from hexokinase to pyruvate kinase, leading to the formation of pyruvate. Since most of the pyruvate is subsequently converted to $\mathrm{CO}_{2}$ and ethanol, we take the production of $\mathrm{CO}_{2}$ and ethanol to be synonymous to glycolytic flux unless indicated otherwise.

Preparation of cell-free extracts and enzyme assays. The preparation of cell extracts by glass bead disruption was as described by De Koning et al. (1991). Enzyme activities were determined spectrophotometrically at $340 \mathrm{~nm}$ and $30^{\circ} \mathrm{C}$. All enzyme assays were performed in $50 \mathrm{~mm}$ PIPES buffer at $\mathrm{pH} 7 \cdot 0$. The assay mixtures for the enzyme assays also contained the following:

Hexokinase $(H K)$ : $02 \mathrm{~mm}-\mathrm{NADP}^{+}, 1 \mathrm{~mm}-\mathrm{ATP}, 10 \mathrm{~mm}-\mathrm{MgSO}_{4}$, $0.56 \mathrm{U}$ glucose-6-phosphate dehydrogenase (G6PDH) $\mathrm{ml}^{-1}, \mathrm{I} \cdot \mathrm{l} \mathrm{U}$ glucose-6-phosphate isomerase (PGI) $\mathrm{ml}^{-1}, 10 \mathrm{~mm}$-fructose.

Glucose-6-phosphate isomerase (PGI): $0.2 \mathrm{mm-NADP}{ }^{+}, 10 \mathrm{~mm}-$ $\mathrm{MgSO}_{4}, 0.56 \mathrm{U} \mathrm{G6PDH} \mathrm{ml} l^{-1}, 2 \mathrm{~mm}$-fructose 6-phosphate.

Phosphofructokinase (PFK): 0.15 mM-NADH, 0.6 mM-ATP, $1 \mathrm{~mm}-$ AMP, $20 \mu \mathrm{M}$-fructose 2,6-bisphosphate, $5 \mathrm{mM}-\left(\mathrm{NH}_{4}\right)_{2} \mathrm{SO}_{4}, 5 \mathrm{mM}$ $\mathrm{MgSO}_{4}, 1.5 \mathrm{U}$ aldolase $\mathrm{ml}^{-1}, 10 \mathrm{U}$ triose-phosphate isomerase $\mathrm{ml}^{-1}$, $0.8 \mathrm{U}$ glycerol-3-phosphate dehydrogenase $\mathrm{ml}^{-1}, 3$ mm-fructose 6 phosphate.
Triosephosphate isomerase $(T P I): 0.4 \mathrm{~mm}-\mathrm{NAD}^{+}, 2 \mathrm{mM}$-arsenate, $1 \cdot 6 \mathrm{U}$ glyceraldehyde-3-phosphate dehydrogenase (GAPDH) $\mathrm{m}^{-1}$, 3 mM-dihydroxyacetone phosphate.

Glyceraldehyde-3-phosphate dehydrogenase (GAPDH): $0.15 \mathrm{~mm}$ NADH, I mM-ATP, 5 mм-MgSO, 0.9 mm-EDTA, 0.2 mM-DTT, 13.5 U PGK ml ${ }^{-1}, 3$ mM-3-phosphoglycerate (3-PGA).

3-Phosphoglycerate kinase $(P G K): 0.15 \mathrm{~mm}-\mathrm{NADH}, 5 \mathrm{~mm}-\mathrm{MgSO}_{4}$, 0.9 mM-EDTA, 1 mM-ATP, 1.6 L GAPDH ml-1, 3 mM-3-PGA.

Phosphoglycerate mutase $(P G M): 0.15 \mathrm{~mm}-\mathrm{NADH}, 1 \mathrm{mM}-\mathrm{ADP}$, $0 \cdot 12 \mathrm{~mm}$-glycerate-2,3-diphosphate (2,3-PGA), $5 \mathrm{~mm}-\mathrm{MgSO}_{4}, 0 \cdot 9 \mathrm{~mm}$ EDTA, $2.8 \mathrm{U}$ lactate dehydrogenase $(\mathrm{LDH}) \mathrm{ml}^{-1}, 1.4 \mathrm{U}$ pyruvate kinase (PK) $\mathrm{ml}^{-1}, 1.4 \mathrm{U}$ enolase (ENO) $\mathrm{ml}^{-1}, 3 \mathrm{~mm}$-3-PGA.

Enolase (ENO): 0.15 mM-NADH, $1 \mathrm{~mm}$-ADP, $5 \mathrm{~mm}-\mathrm{MgSO}_{4}, 0.9$. mM-EDTA, $2.8 \mathrm{U} \mathrm{LDH} \mathrm{ml^{-1 }}, 1.4 \mathrm{U} \mathrm{PK} \mathrm{m} l^{-1}, 1 \mathrm{~mm}$-2-PGA.

Pyruvate kinase $(P K): 0-15 \mathrm{~mm}-\mathrm{NADH}, 5 \mathrm{~mm}$-phosphoenolpyruvate (PEP), $100 \mathrm{~mm}-\mathrm{KCl}, 30 \mathrm{~mm}-\mathrm{MgSO}_{4}, 1 \mathrm{~mm}$-fructose 1,6-bisphosphate, $1.4 \mathrm{U} \mathrm{LDH} \mathrm{ml}{ }^{1}, 2 \mathrm{~mm}$-ADP.

Pyruvate decarboxylase (PDC): $0.15 \mathrm{~mm}-\mathrm{NADH}, 0.3 \mathrm{~mm}$-dithioerythritol, $0.3 \mathrm{~mm}$-thiaminopyrophosphate, $0.3 \mathrm{~mm}-\mathrm{MgSO}_{4}, 50 \mathrm{~mm}$ $\mathrm{K}_{2} \mathrm{HPO}_{4}, 18 \mathrm{U}$ alcohol dehydrogenase $\mathrm{ml}^{-1}, 100 \mathrm{~mm}$-pyruvate.

Alcohol dehydrogenase $(A D H): 0.15 \mathrm{~mm}-\mathrm{NADH}, 0.1 \%$ bovine serum albumin, I mM-acetaldehyde.

Fructose 1,6-bisphosphatase (FBPase): $0.2 \mathrm{~mm}-\mathrm{NADP}^{+}, 10 \mathrm{~mm}-$ $\mathrm{MgSO}_{4}, \quad 0.1 \mathrm{~mm}$-EDTA, $\quad 0.5 \mathrm{U} \mathrm{PGI} \mathrm{ml}^{-1}, \quad 0.56 \mathrm{U} \mathrm{G6PDH} \mathrm{ml}^{-1}$, 0.35 mM-fructose 1,6-bisphosphate.

Reactions were started by the addition of substrate. All assays were tested for linearity with the quantity of extract. Analyses were performed on a Cobas Bio automatic analyser (Roche). Enzyme activities are expressed in $U$ (mg protein $)^{-1}$ in the extract, where $1 \mathrm{U}$ is equivalent to the conversion of $1 \mu \mathrm{mol}$ of substrate $\mathrm{min}^{-1}$.

Protein was determined by means of the bicinchoninic acid reagent as described by the supplier (Sigma), using bovine serum albumin as a standard.

\section{Results}

\section{cAMP and fructose 2,6-bisphosphate levels do not} correlate with glycolytic flux.

When exponentially growing S. cerevisiae ts 321 or OL 86 cells were transferred from $23{ }^{\circ} \mathrm{C}$ to $36^{\circ} \mathrm{C}$, cell division stopped and cells arrested as large unbudded G1-phase cells. When the same temperature shift was applied to the wild-type strain, A364A, growth rate and cell division rates were increased about twofold for the duration of the experiment (data not shown). The total cellular concentration of cAMP was determined in ts321, OL86 and $\mathrm{A} 364 \mathrm{~A}$ after a switch from $23{ }^{\circ} \mathrm{C}$ to $36^{\circ} \mathrm{C}$. In the $c d c 25-5$ mutant, a sudden drop in the estimated intracellular cAMP level from $0.6 \mu \mathrm{M}$ at permissive temperature to $0 \cdot 15 \mu \mathrm{M}$ after $15 \mathrm{~min}$ at restrictive temperature was observed. Prolonged incubation at $36^{\circ} \mathrm{C}$ resulted in a gradual recovery of the cAMP level to about $0.4 \mu \mathrm{M}$. In the $c d c 25-1$ mutant, the cAMP level responded to the shift in temperature in a dramatically different way. Here the cAMP level rose from $0.5 \mu \mathrm{M}$ at $23^{\circ} \mathrm{C}$ to $1.8 \mu \mathrm{M}$ after $15 \mathrm{~min}$ at $36^{\circ} \mathrm{C}$. When the cells were kept at restrictive temperature for several hours, the cAMP concentration fell to about $1 \mu \mathrm{M}$. These data are in good agreement with observations described earlier by Van 


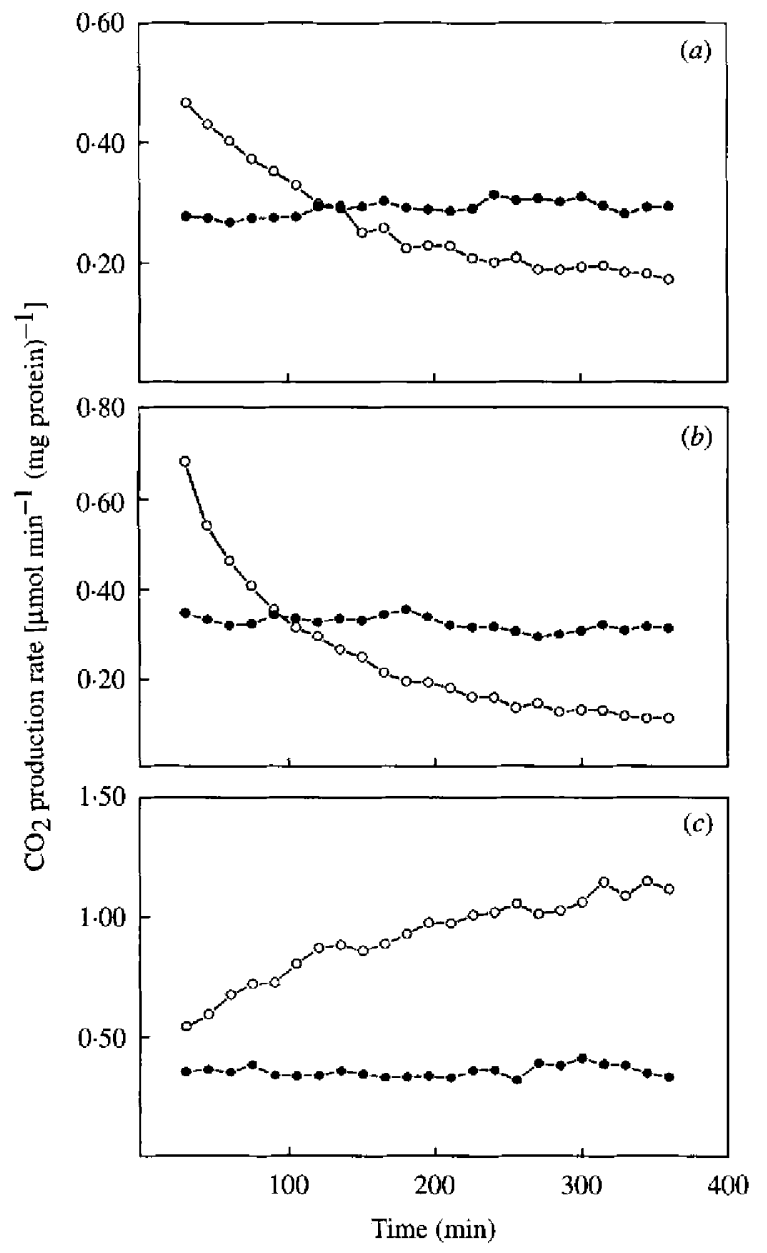

Fig. 1. Specific gas production rates determined in ts 321, OL86 and A364A cultures at permissive temperature (O) or shifted to restrictive temperature at $t=0(O)$. (a) ts321 (cdc25-l) cells; (b) OL86 (cdc25-5); and (c) A364A (wild-type). Gas production rates were determined by direct Warburg manometric measurements.

Aelst $e t$ al. (1991). The pattern of an increase followed by a gradual fall in the cAMP content in response to the temperature shift was also observed in wild-type cells (data not shown).

Fructose 2,6-bisphosphate concentrations in the two $c d c 25$ strains were about $5 \mu \mathrm{M}$ at permissive temperature. When shifted to restrictive temperature for $5 \mathrm{~h}$, the fructose 2,6-bisphosphate level in the $c d c 25-5$ mutant cells dropped to about $1 \mu \mathrm{M}$, whereas the level in $c d c 25$ $l$ carrying cells was not affected.

Glycolytic flux was followed by determining the specific fermentative $\mathrm{CO}_{2}$ production (production per amount of biomass) and the alcohol and glycerol concentrations in the culture. Immediately after the temperature shift, an increase in the $\mathrm{CO}_{2}$ production rate was observed in all strains tested (Fig. 1). This increase is due primarily, if not exclusively, to the increase in incubation temperature. It should be noted that the genetic background of the OL86 strain is different from that of the ts 321 and A364A strains. The stronger (immediate) effect of the temperature shift in $c d c 25-5$ compared to $c d c 25-1$ and wild-type cells may therefore be due to differences in genetic background. Because of the genetic lineage of the OL86 strain it was not possible to compare the $\mathrm{CO}_{2}$ production pattern of the OL86 strain directly with a wild-type strain of the same genetic background. Following the initial rise, the specific $\mathrm{CO}_{2}$ production in the $c d c 25-1$ and the $c d c 25-5$ mutants gradually fell. After $6 \mathrm{~h}$ at restrictive temperature, the production had reached a level that was about half that of the culture kept at permissive temperature. This pattern of $\mathrm{CO}_{2}$ production was similar for both $c d c 25$ alleles tested although in the $c d c 25-5$ cultures the drop appeared to be somewhat steeper than in $c d c 25-1$ cultures. In the wild-type cultures, however, the specific $\mathrm{CO}_{2}$ production rate at $36{ }^{\circ} \mathrm{C}$ increased further after the initial increase at the time of temperature shift. Constancy of the specific gas production rates in all cultures at $23^{\circ} \mathrm{C}$ indicated balanced, exponential growth.

Alcohol concentrations in all cultures were consistent with the observed $\mathrm{CO}_{2}$ production data. Corresponding to the initial increase in $\mathrm{CO}_{2}$ production when cells were shifted from the permissive to the restrictive temperature, the alcohol concentration increased faster at $36^{\circ} \mathrm{C}$ than at $23{ }^{\circ} \mathrm{C}$. After several hours at $36^{\circ} \mathrm{C}$ the alcohol production rate in $c d c 25-1$ and $c d c 25-5$ decreased and the alcohol concentration in the $36^{\circ} \mathrm{C}$ cultures fell below the concentration of the culture kept at $23^{\circ} \mathrm{C}$ (Fig. $2 a, b$ ). In contrast, the ethanol concentration in wild-type cultures continued to increase faster at the higher temperature (Fig. $2 c$ ). In all experiments ethanol production rates, as deduced from the concentration data, and $\mathrm{CO}_{2}$ production rates were about the same (data not shown). As shown in Fig. $2(d, e, f)$ glycerol production in the $c d c 25$ 5 and $c d c 25-1$ cultures at $36^{\circ} \mathrm{C}$ was significantly lower than in wild-type cultures.

Class-II Start cell cycle arrest is accompanied by a drop in glycolytic fux

To investigate whether the decrease in glycolytic flux in $c d c 25-1$ and $c d c 25-5$ was correlated with cell cycle arrest, $\mathrm{CO}_{2}$ production was measured in several thermosensitive $c d c$ mutants, and in cells treated with $\alpha$-mating pheromone (Table 1). The patterns of $\mathrm{CO}_{2}$ production after imposing the restrictive conditions could be divided into two groups. In the first group, the glycolytic fiux after $5 \mathrm{~h}$ under restrictive conditions was somewhat higher than after $30 \mathrm{~min}$ under restrictive conditions. Two cases of Class-I Start arrest $(c d c 28$ and $\alpha$-factor treated cells, Reed, 1980) were found in this group. Also in $c d c 24$ (arresting as multinucleate, unbudded cells) and cdc4 

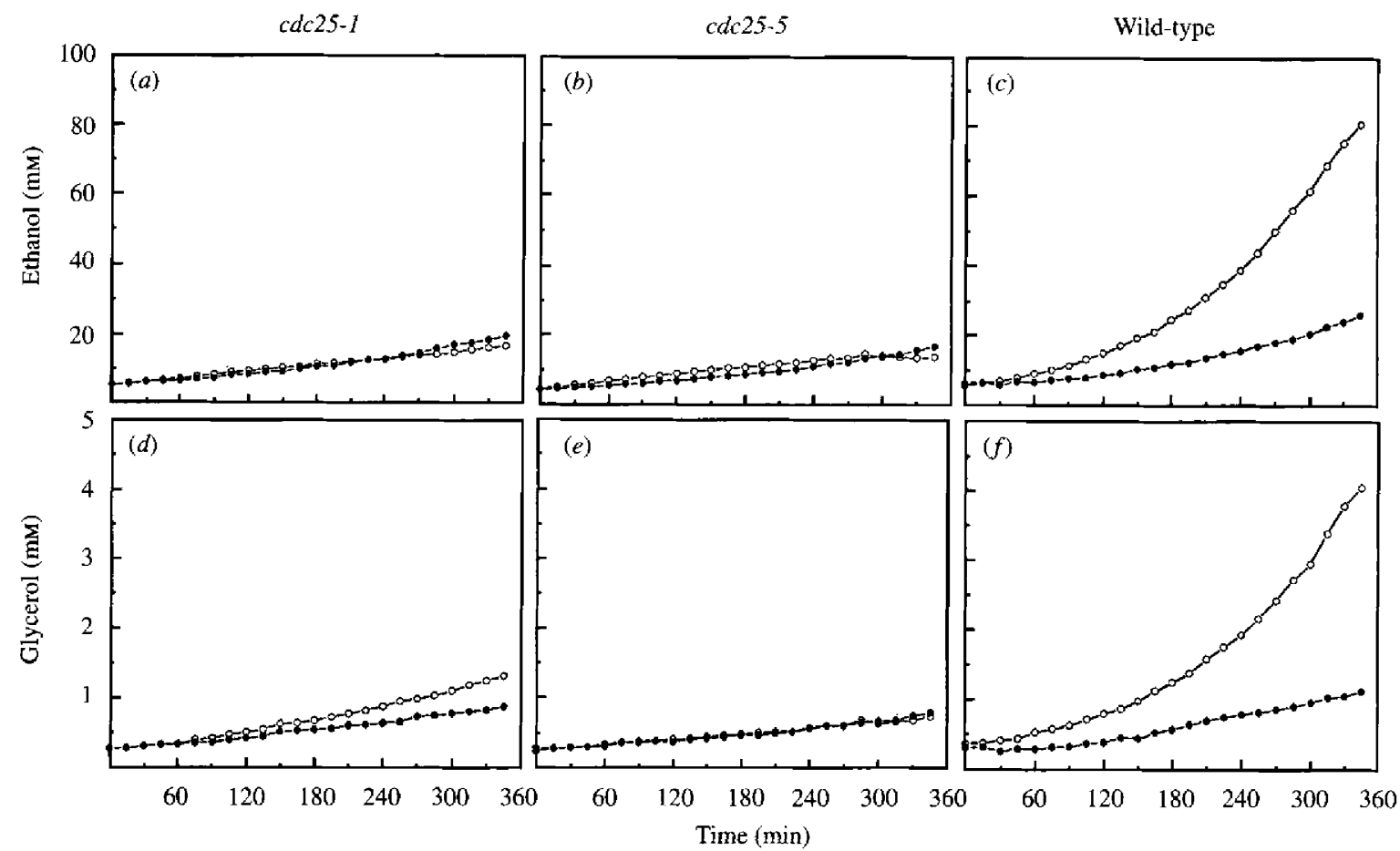

Fig. 2. Ethanol and glycerol concentrations determined in ts321 ( $c d c 25-I)$, OL86 (cdc25-5) or A364A (wild-type) cultures at permissive temperature (-) or switched to $36^{\circ} \mathrm{C}$ at $t=0(O) .(a c)$ Ethanol concentration in ts $321(a)$, OL86 $(b)$, and A364A $(c)$. $(d-f)$ Glycerol concentration in ts321 (d), OL86 (e), and A364A $(f)$. Ethanol and glycerol were determined spectrophotometrically in the medium.

Table 1. $\mathrm{CO}_{2}$ production in cells with different cell cycle blocks

$\mathrm{CO}_{2}$ production was measured under permissive and restrictive conditions for several thermosensitive mutants and $\alpha$-mating factor $\left(4 \mu \mathrm{g} \mathrm{ml}^{-1}\right.$ )-treated $S$. cerevisiae cells. $\mathrm{CO}_{2}$ was determined by direct Warburg manometric techniques.

\begin{tabular}{|c|c|c|c|c|c|c|c|}
\hline \multirow[b]{3}{*}{ Strain } & \multirow{3}{*}{$\begin{array}{l}\text { Relevant } \\
\text { genotype }\end{array}$} & \multirow[b]{3}{*}{ Source* } & \multirow{3}{*}{$\begin{array}{l}\text { Restrictive } \\
\text { condition } \\
\left({ }^{\circ} \mathrm{C}\right) !\end{array}$} & \multicolumn{4}{|c|}{$\mathrm{CO}_{2}$ production [nmol $\left.\mathrm{min}^{-1}(\mathrm{mg} \text { protein })^{-1}\right]$} \\
\hline & & & & \multirow[b]{2}{*}{ Permissive } & \multicolumn{2}{|c|}{ Restrictive } & \multirow{2}{*}{$\begin{array}{c}\text { Ratio } \\
(30: 300 \\
\text { min) }\end{array}$} \\
\hline & & & & & $30 \mathrm{~min}$ & $300 \mathrm{~min}$ & \\
\hline $185-3-4$ & $c d c 28-1$ & (1) & 36 & 454 & 469 & 651 & $0 \cdot 72$ \\
\hline ts 314 & $c d c 4-1$ & (1) & 36 & 391 & 601 & 633 & 0.95 \\
\hline $182-6-3$ & cde24-1 & (1) & 36 & 362 & 513 & 635 & $0 \cdot 81$ \\
\hline $\mathrm{X} 2180-1 \mathrm{~A}$ & wild-type & (1) & $\alpha$-factor & 873 & 660 & 841 & 0.78 \\
\hline ts 395 & cdcI9-1 & (1) & 36 & 169 & 153 & 0 & \\
\hline ts321 & $c d c 25-1$ & (1) & 36 & 290 & 467 & 197 & $2 \cdot 37$ \\
\hline OL86 & $c d c 25-5$ & (2) & 36 & 324 & 685 & 129 & $5 \cdot 31$ \\
\hline E-17 & $c d c 33-1$ & (1) & 36 & 243 & 384 & 85 & 4.99 \\
\hline BR214-4a & $c d c 35-1$ & (1) & 36 & 244 & 426 & 78 & $5 \cdot 46$ \\
\hline PD6517 & cdc $35-10$ & (3) & 37 & 449 & 756 & 260 & $2 \cdot 90$ \\
\hline OL139-1A & $c d c 35-10$ & (2) & 37 & 466 & 685 & 222 & 3.08 \\
\hline ts31FH & ras1 $1^{-}$ts.ras 2 & (3) & 36 & 185 & 252 & 118 & $2 \cdot 14$ \\
\hline
\end{tabular}

* Sources of yeast strains: (1) Yeast Genetic Stock Center, Berkeley, CA, USA; (2) M. Jacquet, Institut Pasteur, Paris, France; (3) J. Thevelein, Leuven, Belgium.

+Permissive temperature was $23^{\circ} \mathrm{C}$ for all yeast strains except for $\alpha$-factor-treated cells, which were grown at $29^{\circ} \mathrm{C}$.

(arresting as uninucleate, multiple-budded cells) the glycolytic flux increased slightiy after prolonged incubation under restrictive conditions.
In the second group, a significant decrease in glycolytic flux was observed under restrictive conditions. All the strains displaying a Class-II type of Start arrest (Reed, 

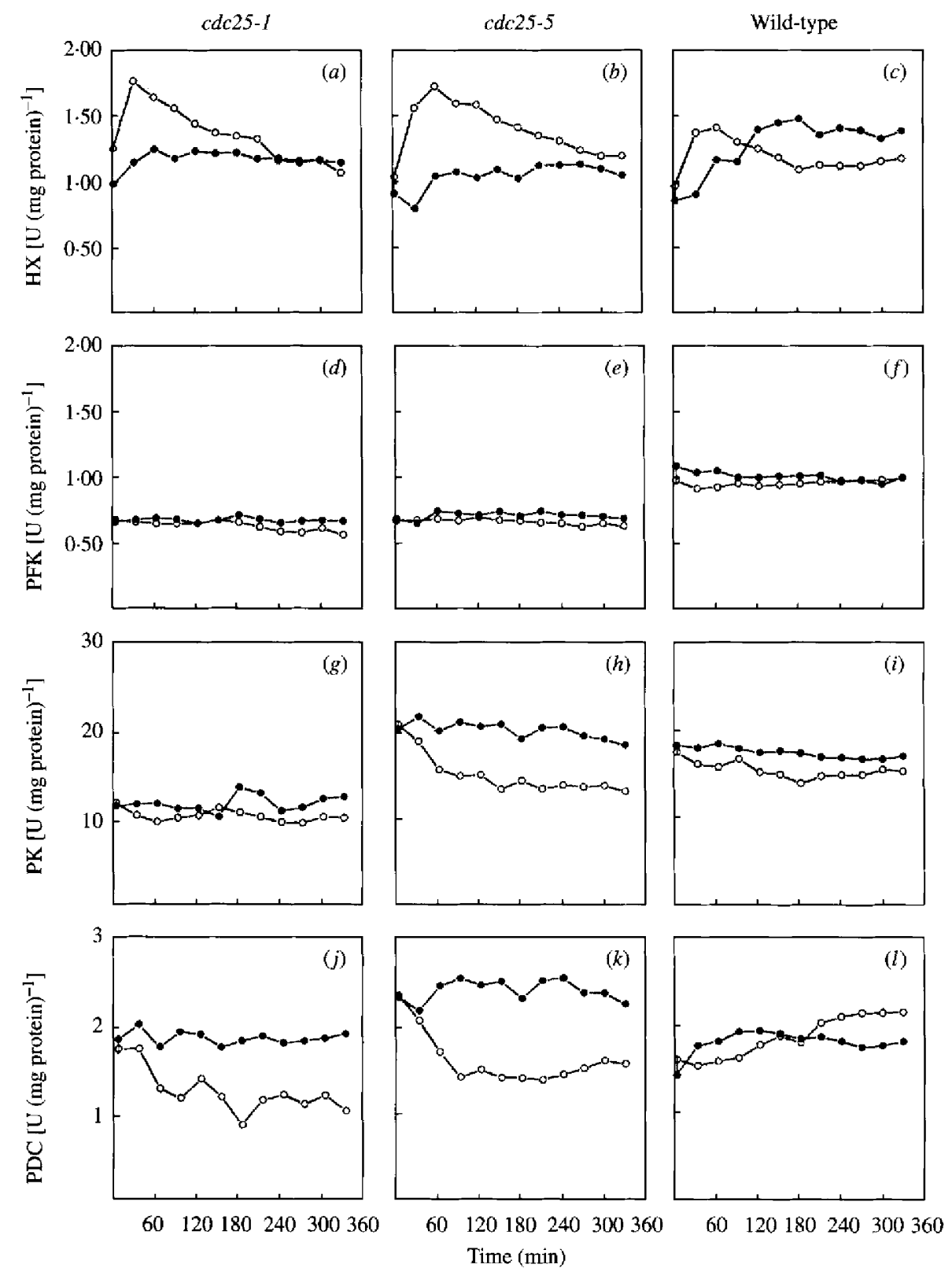

Fig. 3. Glycolytic enzyme activities. Specific activities of hexokinase ( $\mathrm{HX}, a-c)$, phosphofructokinase-1 (PFK, $d-f$ ), pyruvate kinase (PK, $g-i)$ and pyruvate decarboxylase (PDC, $j-l)$. Cells of ts321 (cdc25-I), OL86 (cdc25-5) or A364A (wild-type) were kept at permissive temperature $(\Theta)$ or switched to restrictive temperature at $t=0(O) .\langle a, d, g, j)$ ts 321 cells; $(b, e, h, k)$ OL86 cells; and $(c, f, i, l)$ A364A cells.

1980) were found in this group. After a temperature shift, mutants affected in either adenylate cyclase $(c d c 35$, Boutelet et al., 1985) or RAS (rasI $I^{-}$ts. ras 2$)$ were found to give a similar pattern of $\mathrm{CO}_{2}$ production to the $c d c 25$ mutants. The decrease in glycolytic flux thus seemed to be a general feature of mutants affected in the RAS/ adenylate cyclase pathway. The $c d c 33$ mutant, affected in the protein synthesis initiation factor eiF-4E (Brenner $e t$ al., 1988), was found to give a similar pattern of $\mathrm{CO}_{2}$ production to the mutants affected in the RAS/adenylate cyclase pathway. In the pyruvate kinase mutant $c d c 19-1$ (Gillies \& Benoit, 1983), glycolytic flux was found to decrease dramatically: after $5 \mathrm{~h}$ at $36^{\circ} \mathrm{C}$, no net gas production could be detected by direct Warburg manometric techniques. Differences in glycolytic flux under permissive conditions correlated with differences in growth rate for the various strains (data not shown). In some cases different genetic backgrounds may also play a role. It should be noted that for $\alpha$-factor treated cells, the cultivation temperature was $29^{\circ} \mathrm{C}$, whereas for the 

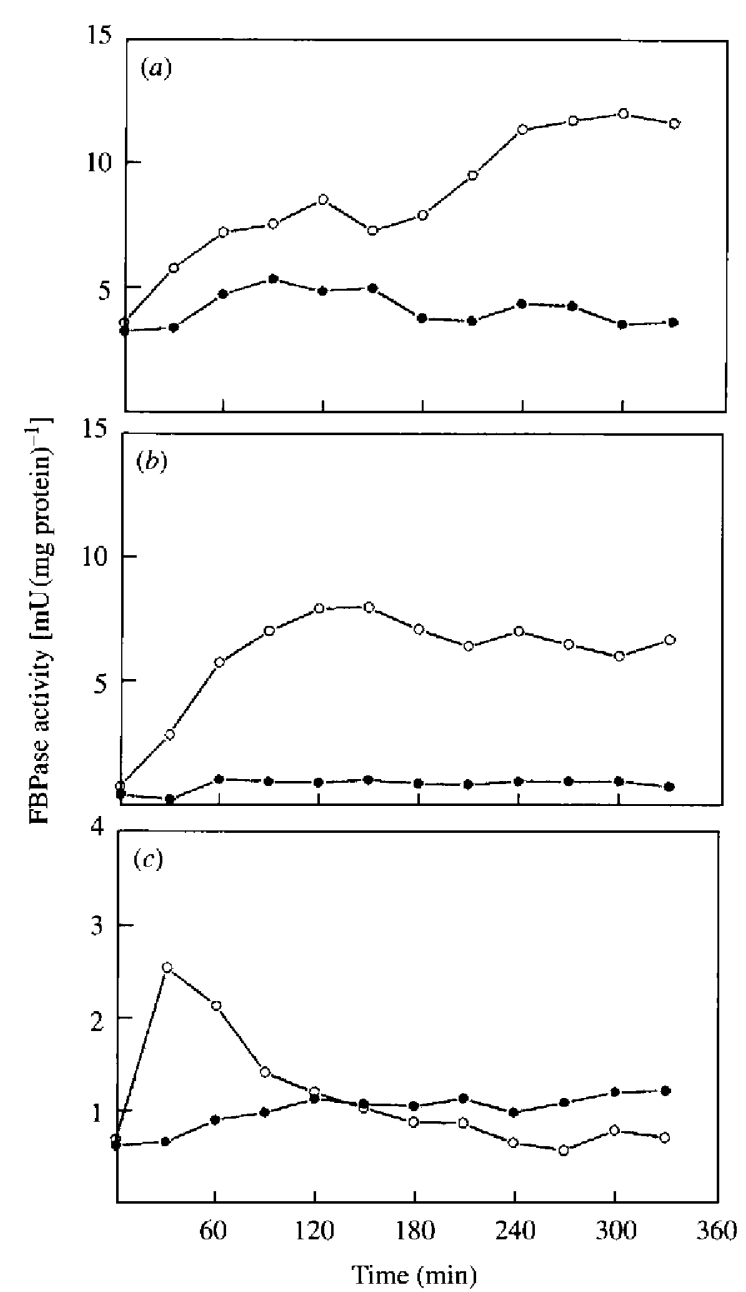

Fig. 4. Specific activities of fructose 1,6-bisphosphatase (FBPase) in ts $321, \mathrm{OL} 86$ and A364A cells at permissive temperature (C) or shifted to restrictive temperature at $t=0(O)$. (a) ts321 (cdc25-l) cells; $(b)$ OL86 (cdc25-5); and (c) A364A (wild-type).

thermosensitive strains a permissive temperature of $23{ }^{\circ} \mathrm{C}$, was used. This presumably explains the relatively high glycolytic activity in the $\alpha$-factor treated cells.

\section{Enzyme activities in cdc25 and wild-type cells}

Since cAMP and fructose 2,6-bisphosphate were reported to affect, amongst others, the activities of PFK1 and FBPase in vitro, we measured the activities of these enzymes in $c d c 25$ mutants and wild-type cells switched from $23{ }^{\circ} \mathrm{C}$ to $36^{\circ} \mathrm{C}$. The activities of PFK1 were found to be constant at both temperatures in all three strains tested (Fig. $3 d, e, f$ ). The same shift from $23{ }^{\circ} \mathrm{C}$ to $36{ }^{\circ} \mathrm{C}$ resulted in a 3-6-fold increase in activity of FBPase in wild-type or $c d c 25$ mutants (Fig. 4). In wild-type cell extracts this increase was transient and the FBPase activity returned to the original level of about $1 \mathrm{mU}$ (mg protein) $)^{-1}$ within $2 \mathrm{~h}$. It should be noted that, compared to the activities of glycolytic enzymes [which were in the order of $U(\operatorname{mg} \text { protein })^{-1}$, the specific activity of FBPase remained very low [in the order of $\mathrm{mU}$ (mg protein) $)^{-1}$.

As a further approach to elucidate the molecular basis of the observed changes in wild-type and $c d c 25$ mutants, the specific activities of most of the glycolytic enzymes were measured after a switch from $23^{\circ} \mathrm{C}$ to $36^{\circ} \mathrm{C}$. The specific activity of most of the glycolytic enzymes was unaffected by the change in growth temperature. In Fig. 3 only data of those glycolytic enzymes whose activity seemed to be somewhat altered by the change in growth temperature are given. We measured virtually constant specific activities at $23{ }^{\circ} \mathrm{C}$ and $36^{\circ} \mathrm{C}$ in all three strains for PGI [average activity about $3.5 \mathrm{U}$ (mg protein) ${ }^{-1}$ ], aldolase $\quad\left[3 \mathrm{U}(\mathrm{mg} \text { protein })^{-1}\right], \quad$ GAPDH $\quad[5 \mathrm{U}$ (mg protein $\left.)^{-1}\right], \quad$ PGK $\left[10 \mathrm{U}(\mathrm{mg} \text { protein })^{-1}\right], \quad$ PGM [12 $\left.\mathrm{U}(\mathrm{mg} \text { protein })^{-1}\right]$, enolase $\left[6 \mathrm{U}(\mathrm{mg} \text { protein })^{-1}\right]$ and $\mathrm{ADH}$ [4 $\left.\mathrm{U}(\mathrm{mg} \text { protein })^{-1}\right]$. None of the glycolytic enzymes of $c d c 25$ mutants showed a decrease which correlated with the observed decrease in in vivo glycolytic flux. Also, none of the glycolytic enzymes in the wildtype cells showed an increase in specific activity which correlated with the observed increase in specific $\mathrm{CO}_{2}$ production rate. Hexokinase activities in the $c d c 25$ mutants at $36^{\circ} \mathrm{C}$ showed a characteristic transient increase from about $1 \mathrm{U}$ (mg protein) $)^{-1}$ to $1.8 \mathrm{U}$ (mg protein) $)^{-1}$ (Fig. $3 a, b$ ). Perhaps the only other glycolytic enzyme with a significant change in specific activity was PDC, whose activity decreased by about $40 \%$ in both $c d c 25$ strains at restrictive temperature (Fig. $3 j, k)$.

As a control experiment, we tested whether the glycolytic enzymes and FBPase in the mutants responded differently in vitro from wild-type to an increase in temperature. The temperature response for all enzymes from mutant cells was the same as in cell extracts of A364A cells. Moreover, no differences in the response to temperature were observed between cells that were incubated at $36^{\circ} \mathrm{C}$ for several hours and cells kept at $23{ }^{\circ} \mathrm{C}$ (data not shown). We therefore assumed that the glycolytic enzymes and FBPase in the $c d c 25$ mutants have a normal temperature response.

\section{Discussion}

cAMP and fructose 2,6-bisphosphate levels do not correlate with glycolytic activity

Regulation of glycolysis in yeasts and other organisms is complex and can occur at several levels ranging from transcriptional control of gene expression to effector controlled modulation of the activity of glycolytic enzymes. cAMP and fructose 2,6-bisphosphate have been suggested to be among the many factors controlling 
glycolytic activity in Saccharomyces cerevisiae (Hers et al., 1985). Although the mechanisms by which cAMP stimulates PFK1 and inhibits FBPase are fairly well understood, their importance in vivo in controlling glycolytic and gluconeogenic fluxes has not received much attention. In this study we compared two thermosensitive mutants which, when shifted to restrictive temperature showed opposite changes in the cAMP level. In the $c d c 25-1$ mutant cAMP levels at restrictive temperature rise and fructose 2,6-bisphosphate levels are unaffected, whereas in $c d c 25-5$ cells at restrictive temperature cAMP levels fall, presumably also causing the observed fall in fructose 2,6-bisphosphate levels. Our cAMP data in ts321 (cdc25-1) and OL86 (cdc25-5) cells confirm observations of Van Aelst et al. (1991), Martegani et al. (1984) and Camonis et al. (1986). Irrespective of the cAMP and fructose 2,6-bisphosphate levels, the specific glycolytic flux appears to show a similar fall in both mutants. Apparently, our experiments show that the cAMP and fructose 2,6-bisphosphate levels per se are not correlated to the glycolytic activity of the cells.

It could be argued that the fall in glycolytic flux at restrictive temperature in both mutants is brought about by different mechanisms. In the $c d c 25-5$ mutant the fall might be correlated with the fall in cAMP and fructose 2,6-bisphosphate levels and in $c d c 25-1$ other mechanisms might operate to reduce the glycolytic flux. Following this line of thought, one would expect PFK1 activity in the $c d c 25-5$ mutant to be reduced through the drop in cAMP and fructose 2,6-bisphosphate and thus glycolytic flux could decrease. We have reason to think that this mechanism to reduce glycolytic activity does not occur: first because we did not observe any change in PFK1 activity when $c d c 25-5$ (or $c d c 25-1$ ) cells were shifted to restrictive temperature; and second because we found that after this shift glucose 6-phosphate and fructose 6phosphate levels do not rise in the $c d c 25-5$ mutant as might be expected if PFK1 activity was lowered (data not shown). In fact, in both $c d c 25-1$ and $c d c 25-5$ mutants glucose 6-phosphate levels were found to drop from about 3-5 mM at permissive temperature to $1-2 \mathrm{~mm}$ at restrictive temperature. ATP levels were not affected by the change in temperature (data not shown). These observations suggest that in both mutants at restrictive temperature, glycolytic flux is inhibited at the very beginning of the pathway, possibly by a reduction of the amount of glucose transported into the cells. Although other explanations are possible, the observation that glycerol production in the $c d c 25$ mutants is much less than in wild-type cells may be interpreted to indicate that the reduction in glycolytic activity takes place before the triose phosphate step of the pathway.

Interestingly, the specific activity of FBPase in both $c d c 25-1$ and $c d c 25-5$ rises at the restrictive temperature.
cAMP and fructose 2,6-bisphosphate have been implicated in the regulation of this enzyme by modulating its phosphorylation state (Tortora et al., 1981; Hers et al., 1985; Rittenhouse et al., 1987). Since the two mutants contain different levels of cAMP and fructose 2,6bisphosphate at the restrictive temperature, but show a similar activation of FBPase activity, these components are not likely to be the key factors in controlling FBPase activity in our experiments. Recently Chiang \& Schekman (1991) presented evidence that glucose catabolite inactivation of FBPase activity occurs through regulated protein import from the cytosol into the yeast vacuole, where the enzyme is degraded. In the $c d c 25$ mutants at restrictive temperature, the observed increase in FBPase activity might thus be due to a reduced import of FBPase into the vacuole. This symptom of 'derepression' of the mutants would fit in with other derepression phenomena generally observed at restrictive temperature such as accumulation of trehalose and glycogen (Petitjean et al., 1990).

Although our data indicate that cAMP and fructose 2,6-bisphosphate levels do not correlate with glycolytic flux or with FBPase activity, it should be stressed that, since our experiments were designed only to look at effects taking place in a time-span of several hours, they leave open the possibility that the cAMP/fructose 2,6bisphosphate mechanism of affecting FBPase and PFK1 activities is important for short-term regulation of glycolytic activity.

\section{Glycolytic enzymes and control of glycolytic fux}

Our measurements of the specific activities of glycolytic enzymes indicate that the activities of these enzymes are unlikely to be the prime factor in the control of glycolytic flux in our cells. This conclusion is based on two observations: (1) the decrease in glycolytic activity of the $c d c 25$ mutants is not accompanied by a similar decrease in the activity of any of the glycolytic enzymes, and (2) the gradual increase in specific glycolytic activity in wildtype cells at $36^{\circ} \mathrm{C}$ is not accompanied by an increase in any of the enzymes. There are other reports that a change in glycolytic activity is not accompanied by a change in the activities of glycolytic enzymes. Lagunas et al. (1982) observed a decrease in glycolytic activity due to the withdrawal of the nitrogen source. They reported that the activities of glycolytic enzymes did not change during the starvation period, and that the decrease in flux was caused by a fall in glucose transport activity in the cells (Lagunas et al., 1982). Also, artificial elevation of the specific activity of several glycolytic enzymes does not affect glycolytic flux. Schaaff et al. (1989) overexpressed eight different glycolytic enzymes by placing their genes on multicopy vectors. Although the specific activity of 
the enzymes was raised between $3 \cdot 7$ - and 14 -fold above the wild-type level, the rate of ethanol formation was not affected. The levels of key glycolytic intermediates were also normal when compared to the wild-type strain. It is always difficult to assess the importance of in vitro data for in vivo phenomena, but all these data seem to indicate that under normal conditions none of the glycolytic enzymes is actually 'rate limiting'. Other factors, such as hexose transport (Lagunas et al., 1982), may be of greater importance in the control of glycolytic flux.

\section{Glycolytic activity and class-II Start arrest}

When thermosensitive mutants in the RAS/adenylate cyclase pathway (rasI $I^{-}$ts. ras $2, c d c 35$ ) and other $c d c$ mutants displaying class-II G1 arrest $(c d c 19, c d c 33)$ are shifted to restrictive temperature, they all show a decrease in glycolytic flux which is similar to the one seen in the $c d c 25$ mutants. In contrast, if $\mathrm{Gl}$ arrest is induced by shifting other thermosensitive mutants ( $c d c 28$ and $c d c 4$ ) to restrictive temperature or by addition of $\alpha$-mating factor to a-cells, the specific glycolytic flux does not drop and continues more or less similar to the wild type. The drop in glycolytic activity therefore does not seem to be caused merely by an arrest in the Gl-phase but seems to be specific for the class-II type of cell cycle arrest at Start. The similarities between $c d c 25$ mutants switched to restrictive temperature and nitrogen starved cells, which also displayed a class-II Start arrest and also showed a drop in glycolytic flux (Lagunas et al., 1982), are striking. As noted above, in both cases the drop in glycolytic activity is not correlated with a major change in the activity of any of the glycolytic enzymes and in both cases the reduction in glycolytic flux may be the result of a decrease in sugar transport. Furthermore it appears that whereas ethanol and $\mathrm{CO}_{2}$ production drop, specific oxygen consumption rates in both situations are not affected in arrested cells (Lagunas et al., 1982; L. J. W. M. Oehlen and others unpublished results). The strong physiological resemblance between the thermosensitive mutants and the nitrogen-starved cells may suggest that similar if not identical, mechanisms are responsible for class-II Start arrest.

One of the characteristics of class-II G1 arrest is that the growth rate of the cells is impeded, whereas in the class-I type of G1 arrest growth of the cells continues more or less as in wild-type cells (Reed, 1980; Pringle \& Hartwell, 1981). It may not be very surprising that in cells which reduce their growth rate, the activity of one of the key pathways driving growth is reduced. It may however be interesting to consider the possibility that regulation of the glycolytic pathway is one of the means by which the cell regulates growth rate and that in StartII arrested cells the decrease in growth rate - and cell- cycle arrest - are the consequence of the decrease in glycolytic flux. To substantiate this line of argument, it is important to realize that the glycolytic pathway is the prime metabolic route in yeast cells. All glucose that enters the cell has to go through at least a few steps of the glycolytic pathway in order to be converted to precursors for protein, RNA, DNA and polysaccharide synthesis. The importance of the glycolytic enzymes is also reflected in the fact that together they comprise about $30 \%$ of the total soluble protein of the cell (Fraenkel, 1982). It is likely therefore that a major decrease in glycolysis will affect cell growth rate. However, the interpretation that cell cycle arrest is merely the consequence of a decrease in glycolytic flux is probably too simple. Although there seems to be a correlation between growth rate and glycolytic flux at restrictive temperature, it is not clear why the $c d c 25$ cells stop dividing shortly after the temperature shift, at a point where cell size and glycolytic activity seem to be sufficient to allow division. One explanation for this may be that inactivation of the CDC25 gene product not only affects growth and glycolytic activity, but that the $\mathrm{CDC} 25$ protein is also more directly involved in the regulation of cell division. It has been proposed that the $\mathrm{CDC} 25$ protein functions in the coordination of growth and division in S. cerevisiae (Baroni et al., 1989). The mechanism by which CDC25 would act in the coordination of growth and division is unclear, but based the cAMP measurements in the two different alleles of $c d c 25$, intracellular cAMP levels per se do not seem to be involved.

We are indebted to the Department of Molecular Cell Biology, University of Amsterdam, for allowing us to use the Coulter counter facilities. We thank Drs J. M. Thevelein and M. Jacquet for providing yeast strains. We also wish to thank Dr Thevelein for stimulating discussions and critical reading of the manuscript. Part of this work was supported by Gist-brocades BV, Delft, The Netherlands.

\section{References}

Baroni, M. D., Martegani, E., Monti, P. \& Alberghina, L. (1989). Cell size modulation by CDC25 and RAS2 genes in Saccharomyces cerevisiae. Molecular and Cellular Biology 9, 2715-2723.

Beck, C. \& Von Meyenburg, K. (1968). Enzyme patterns and aerobic growth of Saccharomyces cerevisiae under various degrees of glucose limitation. Journal of Bacteriology 96, 479-486.

BerNT, E. \& GUTMANN, I. (1974). Ethanol. Determination with alcohol dehydrogenase and NAD. In: Methods of Enzymatic Analysis, vol. 3 , pp. 1499-1502. Edited by H. U. Bergmeyer. New York: Academic Press.

Boutelet, F., Petitjean, A. \& Hil.ger, F. (1985). Yeast $c d c 35$ mutants are defective in adenylate cyclase and are allelic with $c y r 1$ mutants while $C A S 1$, a new gene, is involved in the regulation of adenylate cyclase. EMBO Journal 4, 2635-2641.

Brenner, C., Nakayama, N., Goebl, M., Tanaka, K., Toh-E, A. \& Matsumoto, K. (1988). CDC 33 encodes mRNA cap-binding protein eIF-4E of Saccharomyces cerevisiae. Molecular and Cellular Biology 8, 3556-3559.

Brolk, D., Toda, T., Michael., T., Levin, L., Birchmeier, C., Zoller, M., Powers, S. \& Wigler, M. (1987). The S. cerenisiae 
$c d c 25$ gene product regulates the RAS/adenylate cyclase pathway. Cell 48, 789-799.

Camonis, J. H., Kalekine, M., Gondre, B., Garreau, H., BoyMARCOTE, E. \& JACQUET, M. (1986). Characterization, cloning and sequence analysis of the $C D C 25$ gene which controls the cyclic AMP level of Saccharomyces cerevisiae. EMBO Journal 5, 375-380.

Chiang, H. L. \& Schickman, R. (1991). Regulated import and degradation of a cytosolic protein in the yeast vacuole. Nature, London 350, 313-318.

Clifton, D. \& Fraenkel, D. G. (1983). Fructose 2,6-bisphosphate and fructose 6-phosphate 2-kinase in Saccharomyces cerevisiae in relation to metabolic state in wild type and fructose 6-phosphate 1-kinase mutant strain. Journal of Biological Chemistry 258, 9245-9249.

De Koning, W., Groenteveld, K., Oehlen, L. J. W. M., Berden, J. A. \& VAN DAM, K. (1991). Changes in the activities of key enzymes of glycolysis during the cell cycle in yeast - a rectification. Journal of General Microbiology 137, 971-976.

DE Koning, W. \& VAN DAM, K. (1992). A method for the determination of changes of glycolytic metabolites in yeast on a subsecond time scale using extraction at neutral pH. Analytical Biochemistry 204, 118-123.

FRAENKEL, D. G. (1982). Carbohydrate metabolism. In The Molecular Biology of the Yeast Saccharomyces, pp. 1-37. Edited by J. N. Strathern, E. W. Jones \& J. R. Broach. Cold Spring Harbor NY: Cold Spring Harbor Laboratory.

Francois, J., Van Schaftingen, E. \& Hers, H. G. (1984). The mechanism by which glucose increases fructose 2,6-bisphosphate concentration in Saccharomyces cerevisiae. European Journal of Biochemistry 145, 187-193.

Garreau, H., Camonis, J. H., Guitton, C. \& Jacquet, M. (1990). The Saccharomyces cerevisiae CDC25 gene product is a $180 \mathrm{kDa}$ polypeptide and is associated with a membrane fraction. FEBS Letters 269, 53-59.

Gillies, R. J. \& Benoit, A. G. (1983). NMR analysis of a cell division cycle mutant of Sacharomyces cerevisiae. Biochimica et Biophysica Acta 762, 466-470.

HaRTWell, L. H. (1974). Saccharomyces cerevisiae cell cycle. Bacteriological Reviews 38, 164.

Hers, H. G., François, J. \& Van Schaftingen, E. (1985). Fructose2,6-bisphosphate versus cyclic AMP in the liver and in lower eukaryotic cells. Current Topics in Cellular Regulation 27, 399-410.

Jones, S., Vignais, M. L. \& BRoaCH, J. R, (1991), The CDC25 protein of Saccharomyces cerevisiae promotes exchange of guanine nucleotides bound to Ras. Molecular and Cellular Biology 11, 2641-2646.

Lagunas, R., Dominguez, C., Busturia, A. \& SaCz, M. J. (1982). Mechanisms of appearance of the Pasteur effect in Saccharomyces cerevisiae: inactivation of sugar transport system. Journal of Bacteriology 152, 19-25.

Martegani, E., VANoni, M. \& Baroni, M. (1984). Macromolecular syntheses in the cell cycle mutant $c d c 25$ of budding yeast. European Journal of Biochemistry 144, 205-210.

Matsumoto, K., Uno, I. \& Ishikawa, T. (1985). Genetic analysis of the role of cAMP in yeast. Yeast 1, 15-24.

MUNDER, T. \& KunTzEL, H. (1989). Glucose-induced cAMP signalling in Saccharomyces cerevisiae is mediated by the CDC25 protein. FEBS Letters 242, 341-345.

Nissler, K., Otto, A., Schellenderger, W. \& Hofmann, E. (1983). Similarity of activation of yeast phosphofructokinase by AMP and fructose-2,6-bisphosphate. Biochemical and Biophysical Research Communications 111, 294-300.

NovaK, B. \& Mitchison, J. M. (1986). Change in the rate of $\mathrm{CO}_{2}$ production in synchronous cultures of the fission yeast Schizosaccharomyces pombe: a periodic cell cycle event that persists after the DNA-division cycle has been blocked. Journal of Cell Science $\mathbf{8 6}$, 191-206.

Ortiz, C. H. D., Maia, J. C. C., Tenan, M. N., Braz-Pradao, G. R., Mattoon, J. R. \& PaneK, A. D. (1983). Regulation of yeast trehalase by a monocyclic, cyclic AMP-dependent phosphorylationdephosphorylation cascade system. Journal of Bacteriology 153, 644651 .

Petitjean, A., Hilger, F. \& Tatchell, K. (1990). Comparison of thermosensitive alleles of the CDC25 gene involved in the CAMP metabolism of Saccharomyces cerevisiae. Genetics 124, 797-806.

POHL.IG, G. \& HolzER, H. (1985). Phosphorylation and inactivation of yeast fructose 1,6-bisphosphatase by cyclic AMP-dependent protein kinase from yeast. Journal of Biological Chemistry 260, 13818-13823.

Pringle, J. R. \& Hartwell, L. H. (1981). The Saccharomyces cerevisiae cell cycle. In The Molecular Biology of the Yeast Saccharomyces, pp. 97-142. Edited by J. N. Strathern, E. W. Jones \& J. R. Broach. Cold Spring Harbor NY: Cold Spring Harbor Laboratory.

Purwin, C., Leidig, F. \& Holzer, H. (1982). cAMP-dependent phosphorylation of fructose 1,6-bisphosphatase in yeast. Biochemical and Biophysical Research Communications 107, 1482-1489.

REED, S. I. (1980). The selection of Saccharomyces cerevisiae mutants defective in the start event of cell division. Genetics 95, 561-577.

RitTenhouse, J., Moberly, L. \& MarCus, F. (1987). Phosphorylation in vivo of yeast (Saccharomyces cerevisiae) fructose-1,6bisphosphatase at the cyclic AMP-dependent site. Journal of Biological Chemistry 262, 10114-10119.

SchaAfF, I., Heinisch, J. \& ZimmermanN, F. K. (1989). Overproduction of glycolytic enzymes in yeast. Yeast 5, 285-290.

Tanaka, K., Matsumoto, K. \& Toh-E, A. (1988). Dual regulation of the expression of the polyubiquitin gene by cyclic AMP and heat shock in yeast. EMBO Journal 7, 495-502.

Tortora, P., Birtel, M., Lenz, A. G. \& Holzer, H. (1981). Glucosedependent metabolic interconversion of fructose-1,6-bisphosphatase in yeast. Biochemical and Biophysical Research Communications 100, 688-695.

Tovey, K. C., Oldham, K. G. \& Whelan, J. A. M. (1974). A simple direct assay for cyclic AMP in plasma and other biological samples using an improved competitive binding technique. Clinica Chimica Acta 56, 221-234.

Umbreit, W. W., Burris, R. H. \& Stalffere, J. S. (1964). Manometric Techniques. Mineapolis: Burgess.

Uno, I., Matsumoto, K., Adachi, K. \& Ishikawa, T. (1983). Genetic and biochemical evidence that trehalase is a substrate of cAMPdependent protein kinase in yeast. Journal of Biological Chemistry 258, 10867 10872.

Van Aelst, L., Boy-Marcotte, E., Camonis, J. H., Thevelein, J. M. \& JaCQueT, M. (1990). The C-terminal part of the CDC25 gene product plays a key rolc in signal transduction in the glucose-induced modulation of cAMP level in Saccharomyces cerevisiae. European Joumal of Biochemistry 193, 675-680.

VAN AeLST, L., JANS, A. W. H. \& ThPVELEIN, J. M. (1991). Involvement of the $c d c 25$ gene product in the signal transmission pathway of the glucose-induced RAS-mediated cAMP signal in the yeast Saccharomyces cerevisiae. Joumal of General Microbiology 137, 341-349.

Van Doorn, J., Valkenburg, J. A. C., Scholte, M. E., Oehlen, L. J. W. M., Van Driel, R., Postma, P. W., Nanninga, N. \& Van Dam, K. (1988). Changes in activities of several enzymes involved in carbohydrate metabolism during the cell cycle. Journal of Bacteriology 170, 4808-4815.

VAN SCHAFTINGEN, E. \& Hers, H. G. (1983). Fructose 2,6-bisphosphate in relation with the resumption of metabolic activity in slices of Jerusalem artichoke tubers. FEBS Letters 164, 195-200.

Vanoni, M., Vavassori, M., Frascotti, G., Martegani, E. \& AlBerGHiNA, L. (1990). Overexpression of the $c d c 25$ gene, an upstream element of the Ras adenylyl cyclase pathway in Saccharomyces cerevisiae, allows immunological identification and characterization of its gene product. Biochemical and Biophysical Research Communications 172, 61-69.

Wieland, O. (1974). Glycerol. In Methods of Enzymatic Analysis, vol. 3, pp. 1404 1409. Edited by H. U. Bergmeyer. New York: Academic Press. 